\title{
"O meu avô me contava": dinâmicas de circulação da memória do cativeiro entre descendentes de escravos. Osório, século XX
}

\author{
Rodrigo de Azevedo Weimer*
}

\section{Introdução}

Dona Eva Marques Correia, 88 anos em 2010, sabe contar histórias do tempo dos escravos da fazenda do Morro Alto, dos quais descende. Esta antiga propriedade escravista localizava-se no litoral norte do estado do Rio Grande do Sul, onde atualmente é a divisa entre os municípios de Osório e Maquiné. Compreende diversas localidades, dentre as quais a denominada Morro Alto, no entroncamento das estradas BR-101 com a RS-407. Os extremos meridional e setentrional da fazenda são as localidades de Aguapés e Espraiado, unidas recentemente por um túnel da BR-101 que corta caminho por baixo do morro. A leste, segue rumo a Capão da Canoa ao longo da RS407, na localidade denominada Faxinal do Morro Alto, até o canal denominado Barra do João Pedro, que liga o rio Maquiné à lagoa das Malvas.

* Doutorando em História na Universidade Federal Fluminense (UFF). Esta pesquisa conta com o apoio do CNPq - Brasil. A fim de preservar o tom oral e manter a naturalidade das citações de entrevistas, optou-se por não realizar sua correção gramatical, mantendo "erros", tanto na fala do entrevistador quanto dos entrevistados. 
Seu avô lhe contava que, após fustigados no tronco, os escravos eram colocados em cima de formigueiros. ${ }^{1}$ Além dos sofrimentos e dos castigos físicos que eram impostos, sabe do terreno deixado em herança por uma senhora escravista para seus cativos e tem, até mesmo, condiçóes de nomear os velhos que conheceu em sua infância que passaram pela experiência do cativeiro ou as atividades produtivas a que se dedicavam. Tal conhecimento é possível por ter convivido, quando criança, com ex-escravos idosos, principalmente sua avó Felisberta e seu avô Merêncio. ${ }^{2}$

Seus filhos, por seu turno, Maria e Arli Marques Correia, 58 e 64 anos em 2010, pouco sabem das experiências do cativeiro vividas por seus ancestrais. Eles têm a ciência de que seus bisavós foram escravos, porém guardam uma memória difusa e inespecífica da realidade do cativeiro, não sabendo nomeá-los ou exemplificar experiências por que passaram. As representações da escravidão frequentemente são inspiradas por telenovelas. Apesar de terem convivido bastante com sua avó materna Mercedes, filha da escrava Felisberta, com ela aprenderam lides rurais, mas não histórias sobre o cativeiro. ${ }^{3}$

Utilizo o termo "transmissão" da memória do cativeiro sempre entre aspas porque, afinal, como veremos, a passagem intergeracional da memória da escravidão obedeceu a critérios mais complexos do que a mera reprodução daquilo que os avós lhes contavam; foi processada e decodificada conforme critérios contemporâneos de avaliação. Janotti e Rosa (1995) abordam a transmissão da memória sobre a escravidão, sem aspas. Embora as autoras tenham claro que o relato de vida não é esclarecedor de fatos passados, e sim uma interpretação atual a respeito dos mesmos e, ainda, que a memória trata de uma reconstrução dinâmica em parâmetros sociais, elas remetem aos "primeiros narradores" e aos "depositários" de sua narrativa sem problematizar os processos de "narração", sua "transmissão" e as mediações implicadas.

1 Participação de dona Eva Marques Correia em entrevista com Arli Marques Correia e Maria Marques Correia Mendes, no dia 19 de novembro de 2010, no Caconde.

2 Entrevistas com dona Eva Marques Correia, nos dias 14 de janeiro de 2009 e 12 de março de 2010, no Caconde.

3 Entrevista com Arli Marques Correia e Maria Marques Correia Mendes, no dia 19 de novembro de 2010, no Caconde. 
O padrão de "transmissão" da memória da escravidão que descrevi brevemente para o caso da família de dona Eva é comum a famílias afins. Também entre primos de Eva Marques Correia, pessoas octogenárias sabem detalhadas histórias do tempo do cativeiro por as terem ouvido de avós escravos, ao contrário da geração imediatamente posterior, que não ouviu essas narrativas dos pais de seus pais, nascidos livres. Neste artigo, analiso a memória da escravidão entre netos e bisnetos de escravos pertencentes a uma família oriunda de uma antiga propriedade escravista no litoral norte do Rio Grande do Sul. Contudo, não abordo a memória no que toca ao conteúdo destas lembranças - o que estou realizando em estudo mais amplo - mas sim às dinâmicas de transmissão e reprodução das recordaçôes do cativeiro.

Discuto, assim, as razões pelas quais a memória do cativeiro salta gerações, reproduzindo-se no circuito avô-neto, e não pai-filho; e analiso os motivos que levaram a primeira geração nascida após o cativeiro a evitar reproduzir sua memória entre seus netos, enquanto os próprios cativos contaram tais histórias aos filhos de seus filhos. Finalmente, no que toca à geração dos netos de escravos, fujo à ideia de uma simples "transmissão" de memórias, buscando em suas experiências de inserção no mercado de trabalho as condições através das quais aquelas memórias familiares sobre o cativeiro conservaram atualidade. Na "transmissão" de uma memória, o polo "receptor" assimila, reinterpreta, rememora e reproduz as narrativas em questão, e são esses imperativos, operados pelo presente, que levam a falar ou a silenciar sobre as memórias do passado. Pensando o discurso oral como um texto, há que atribuir ao "ouvinte" as mesmas práticas ativas de recepção através das quais o lugar do "leitor" vem sendo pensado (Certeau, 1994; Chartier, 1998).

Entende-se aqui, com Portelli (1997, p. 16), a memória como um processo, e não como um depósito de dados. Segundo Catroga (2001, p. 20), "ela não é um armazém que, por acumulação, recolha todos os acontecimentos vividos por cada indivíduo, um mero registo; mas é retenção afectiva e 'quente' do passado feita dentro da tensão tridimensional do tempo". Trata-se de analisar a memória não apenas como fonte de conhecimento histórico da qual se extraem informações sobre fatos e processos históricos pretéritos, mas ela mesma como objeto de reflexão. Em outros termos, busca-se inscrever esses processos de memória em sua historicidade e dinâmicas específicas. No caso da presente pesquisa, "analisar como a memória histórica de um grupo constitui-se e transmite-se, como ela ajuda a reforçar sua identidade e a assegurar sua permanência” (Raphaël, 1980, p. 127, tradução minha). 


\section{Os mais novos não sabem tanto por causa da televisão}

Em uma visita à prima de dona Eva, Aurora Inácia Marques da Silva, também neta da escrava Felisberta, procurei obter com ela novas indicações de familiares com quem eu pudesse conversar e gravar entrevistas. Ela procurou me demover de dar continuidade à pesquisa, afinal, eu já havia entrevistado todos os velhos, e os mais novos "não sabem tanto". ${ }^{4}$ Percebe-se neste fato uma pressuposição de quais histórias me interessariam e de quem seriam os capacitados para reproduzi-las. Nessa tentativa de desqualificar os narradores mais novos, percebe-se uma autoafirmação como guardiã da memória e, no limite, uma postura de posse em relação ao entrevistador. De qualquer forma, atribuía à televisão o fato de se terem perdido os referenciais de uma memória familiar que se reproduziria de geração em geração.

Segundo Aurora, quando não existia televisão, os jovens sentavam-se ao redor do fogo, de uma fogueira no interior da casa, ${ }^{5}$ para conversar com os mais velhos, que lhes contavam quem eram seus avós, seus bisavós, o que faziam e de onde vinham. Com o advento da televisão, tal canal de comunicação entre jovens e velhos se perdeu, pois as pessoas só querem saber de assistir seus programas prediletos. Triunfante, Aurora perguntou à sua sobrinha ali presente se sabia o nome de sua bisavó e, diante do desconhecimento dela, Aurora demonstrou conhecer o nome de suas próprias bisavós por parte de pai e de mãe.

Embora a narrativa de dona Aurora leve a crer em uma "transmissão" geracional da memória da escravidão, inclino-me a perceber circuitos falhados entre gerações. Não há dúvida de que a sociedade industrial, a urbanização, a proletarização e o advento da televisão como fonte de informações, ao contrário dos relatos dos idosos, tiveram um impacto fundamental e decisivo sobre as formas de recordar e legar a novas gerações as recordações que se tem. Tanto Cleci Terra da Silva, sobrinha de dona Aurora, quanto Maria Marques Correia, filha de dona Eva, trazem uma representação do cativeiro bastante informada por telenovelas como Sinhá Moça, reprisada na ocasião em que lá andei fazendo pesquisa de campo, ou filmes como Amistad. A ênfase das narrativas diz respeito aos sofrimentos e às situações de crueldade característicos

\footnotetext{
4 Diário de campo, 19 de novembro de 2010. Visita à casa de dona Aurora Inácia Marques da Silva.

5 Existia a prática de, nas casas de pau a pique, acender o fogo no interior da residência para aquecê-la.
} 
do cativeiro, em lugar dos vínculos familiares solidários que os cativos teceram entre si, sempre presentes nos relatos de seus pais. O realismo do suporte fílmico confere, talvez, uma credibilidade ainda maior do que os relatos de seus velhos pais e tios, o que inclusive ajuda a criar um bloqueio quanto à possibilidade de se acreditar na veracidade de tamanhas barbaridades que, no entanto, se sabem verdadeiras.

Cleci - Eu acho tão horrível isso aí, que acho que não foi real. Até tu vê naqueles filmes, tu vê aquelas novelas, sabe aquele navio, atiravam no mar assim, e tratavam no... sabe? É... que nem bicho, aquela coisa que era mesmo. Nem bicho tu não vê hoje em dia. Então, eu acho tão horrível, tão horrível, tão horrível que eu não consigo. A minha cabeça não... Rodrigo - Mas deixa eu te fazer uma pergunta. Uma dúvida que eu tenho. $\mathrm{O}$ que tu sabe disso, tu acha que vem mais da televisão, do que tu vê em filme, ou que vem mais o que a tua tia te contou? Cleci - Ah, não, eu vejo muito na televisão, né? A tia conta, é como eu te disse, eu não quero acreditar, eu sei que é verdade, mas é tipo um bloqueio, né? É tão horrível o que os meus antepassados passaram que eu não consigo... até aceitar, de tão horrível que eu acho. Mas não quer dizer que eu não acredite, porque com certeza, né... ${ }^{6}$

No entanto, mesmo Arli Marques Correia, 64 anos em 2010, que não se criou sob influência da televisão e muito conviveu com sua avó materna, denota uma lacuna nos seus relatos no que toca à memória da escravidão. A explicação que atribui à televisão a interrupção dos circuitos de memória do cativeiro pode ser suficiente e válida para dona Aurora, mas para fins desta pesquisa, merece ser um pouco mais esmiuçada e questionada. Entende-se aqui que, para além de fatores externos ao processo de recordar, cabe buscar nas próprias dinâmicas da memória uma explicação para os lapsos e as diferenças geracionais do que se recorda e do que se esquece. Para isso, veremos os circuitos da memória da escravidão entre escravos, seus filhos, netos e bisnetos.

6 Entrevista com Cleci Terra da Silva, no dia 21 de novembro de 2010, em Osório. Na ocasião, a entrevistada tinha 52 anos. 


\section{Memórias da escravidão atravessando gerações}

Catroga (2001, p. 27) assinala que a memória do indivíduo é, em primeira instância, uma memória familiar. É no ambiente doméstico que "melhor se poderá surpreender os laços que existem entre identificação, distinção, transmissão e a sua interiorização como norma", possibilitando a reprodução do "espírito de família" e do sentimento de pertencimento a ela através de narrativas e outros referenciais simbólicos ou materiais:

os complexos, as reminiscências comuns e as repetições rituais (festas familiares), a conservação de saberes e símbolos (fotografias e respectivos álbuns, a casa dos pais ou dos avós, as campas e mausoléus, os marcos de propriedade, os papéis de família, os odores, as canções, as receitas de cozinha, a patronímia, os nomes), a par da responsabilidade da transmissão do conteúdo das heranças (espirituais e materiais), são condições necessárias para a criação de um sentimento de pertença em que os indivíduos se reconheçam dentro de totalidades genealógicas que, vindas do passado, pretendem, sem solução de continuidade, projectar-se no futuro. (Catroga, 2001, p. 27).

A fim de melhor dar conta dos circuitos geracionais de reprodução de tais reminiscências comuns, no que tange às narrativas orais, apresento organogramas nos quais disponho graficamente os circuitos da narrativa de memórias da escravidão conforme me relataram os entrevistados sobre quem lhes contava histórias do tempo da escravidão. Os indivíduos foram organizados de acordo com gerações, e estas, conforme seu estatuto jurídico. As flechas vermelhas representam narrativas sobre o cativeiro circulando de indivíduos mais velhos a outros mais novos. A ausência de flechas significa a omissão dos entrevistados em relação à existência de tais relatos, ou sua negação explícita que, contudo, não representei graficamente para não tornar os gráficos demasiadamente poluídos. De qualquer maneira, casos de avós que não contaram a seus netos narrativas do cativeiro serão analisados em breve. 


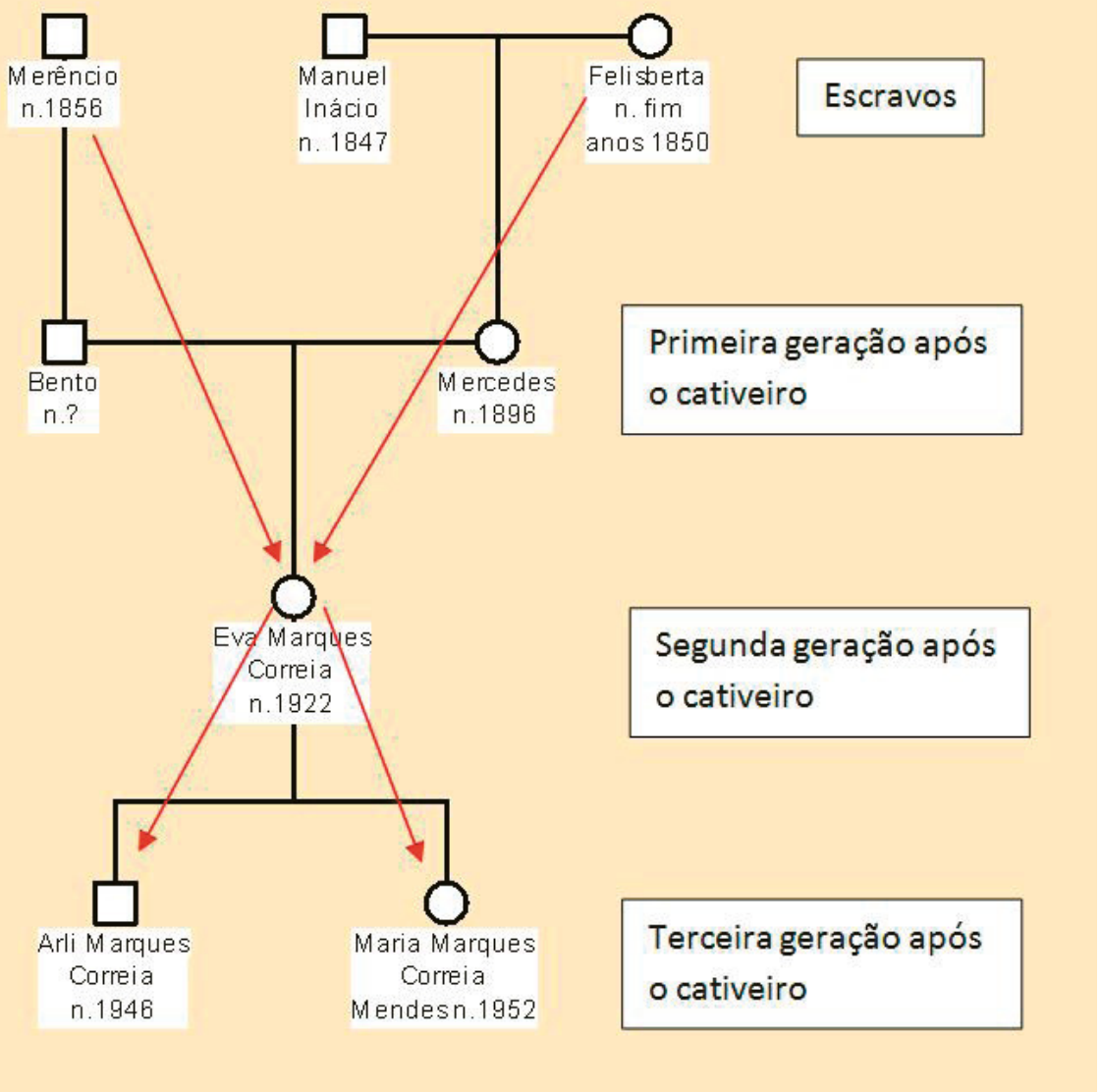

Organograma 1. Relatos a respeito da memória da escravidão na família de Eva Marques Correia (Fonte: entrevistas com integrantes da família e registros paroquiais de batismo de Osório - Arquivo da Cúria Diocesana de Osório e Igreja de Jesus Cristo dos Santos dos Últimos Dias). 


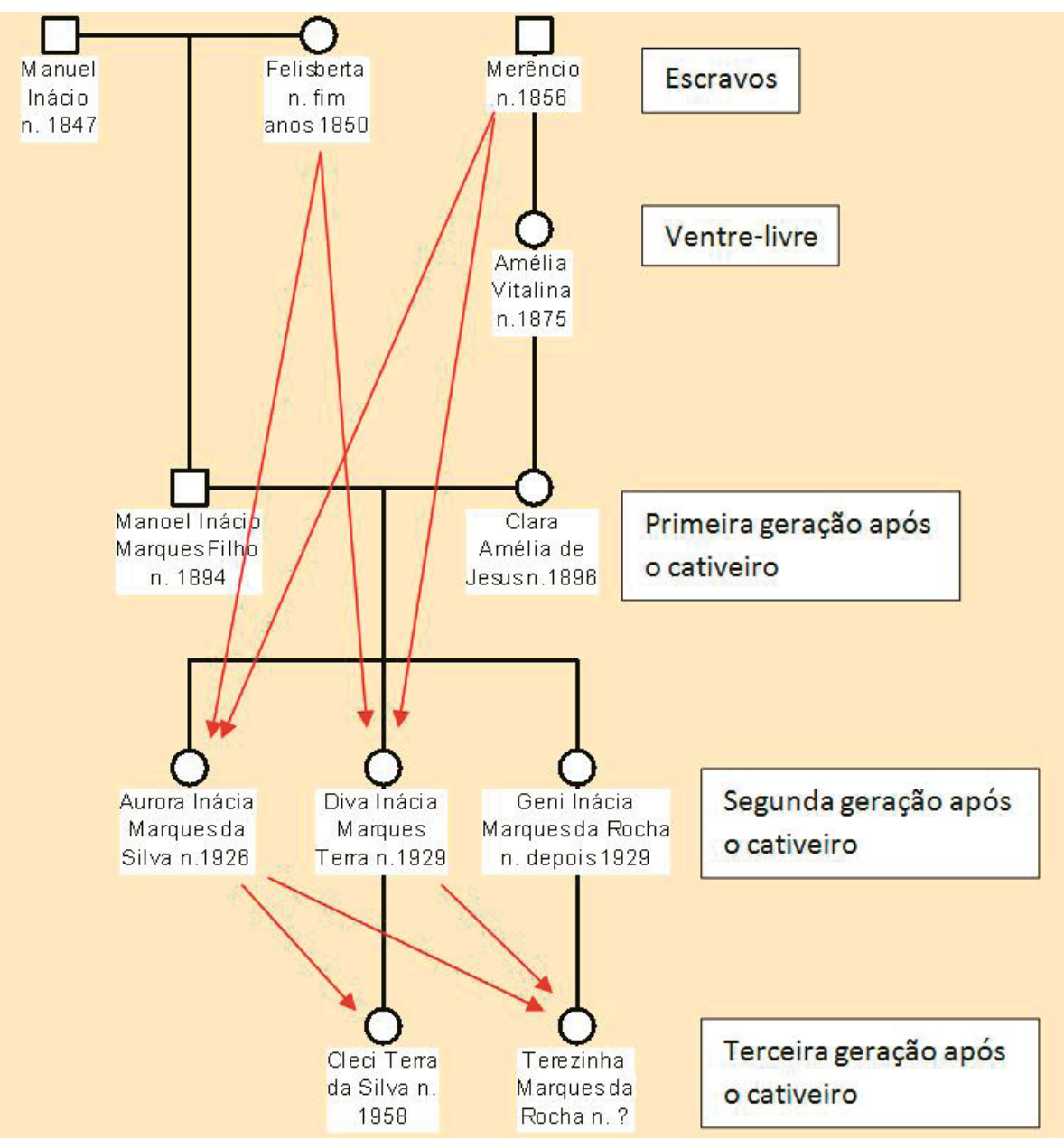

Organograma 2. Relatos a respeito da memória da escravidão nas famílias de Aurora Inácia Marques da Silva e Diva Inácia Marques Terra (Fonte: entrevistas com integrantes da família, registros paroquiais de batismo de Osório - Arquivo da Cúria Diocesana de Osório e Igreja de Jesus Cristo dos Santos dos Últimos Dias - e registros civis de casamento do distrito de Maquiné - Igreja de Jesus Cristo dos Santos dos Últimos Dias).

Percebe-se, em ambos casos, que a geração hoje octogenária sabe histórias do tempo do cativeiro através de relatos dos avós. Trata-se de um conhecimento sistematicamente "transmitido" no circuito avô-neto. Seus filhos, por sua vez, sabem de histórias do tempo do cativeiro através de seus pais e tios, 
e não através dos avós. Há uma diferença fundamental, porém. Eva, Aurora e Diva sabem, ou julgam saber por lhes terem sido contadas histórias por seus avós. Trata-se de um saber sistemático e diante do qual apresentam certeza. Arli, Maria, Cleci e Terezinha associam às mães e às tias o pouco que sabem, recusando-se a dar maiores depoimentos, a geração anterior sendo, assim, a mais autorizada. Seu saber apresenta-se como residual. Inclusive, na entrevista realizada com Arli e Maria, dona Eva encontrava-se presente e, diante do desconhecimento alegado pelos filhos, tomou a iniciativa de relatar histórias que o avô lhe contava, que eram, então, desveladas para o pesquisador, mas também para os filhos da narradora durante o processo de entrevista.

São recorrentes os relatos de crianças criadas pelos avós - e que cuidavam dos mais velhos - enquanto seus pais trabalhavam, tanto na segunda quanto na terceira geração após o cativeiro. Assim, os idosos participavam ativamente da educação das crianças, e esta era uma realidade no meio rural e também no urbano. Já migrados para Osório, na família de Aurora e Diva, a avó Clara cuidou de seus netos Cláudio e Cleci, e criou Terezinha e irmãos que perderam sua mãe muito cedo. A prioridade de tios e avós como pais de criação de crianças sem pais é analisada pela antropóloga Daisy Barcellos (Barcellos et al., 2004 p. 218-219). Os aprendizados adquiridos com os avós eram formativos para a criança e internalizados como válidos. Isto se dava de tal forma que a alegação "meu avô me contava" é suficiente para conferir veracidade a um relato.

No caso, aquilo que Merêncio e Felisberta relataram a respeito do cativeiro pôde ser acionado pelos seus netos em diversos momentos de suas vidas, fazendo parte de um repertório de experiências a partir do qual, como explicarei em breve, avaliaram suas próprias experiências de inserção no mercado de trabalho. Ao mesmo tempo, quando indagados sobre histórias do tempo do cativeiro, Arli, Maria, Cleci e Terezinha puderam alegar que seus avós não lhes falavam. As histórias de tios e pais foram ouvidas de forma eventual, quando já adultos, e não como parte do processo educacional e formativo verificado entre avós e netos.

O fato é que as avós Mercedes e Clara (os entrevistados não conviveram com os avós Bento e Manoel Inácio) foram apontadas pelos entrevistados, uma vez instados por mim, como pessoas que sabiam histórias do tempo dos escravos mas não queriam contar. Nestes casos, a ausência de flechas não significa meu desconhecimento sobre se existiam ou não esses circuitos da memória, mas sua efetiva inexistência. 
Rodrigo - E me diz uma coisa, ela [Mercedes] contava história do tempo da escravidão?

Eva - Não, a minha mãe não foi escrava.

Rodrigo - Ela não sabia de história que falava?

Eva - Ela sabia, mas ela não contava. Ela sabia, porque a mãe dela foi escrava, né? E o sogro também. ${ }^{7}$

Cleci, no caso de sua avó Clara, esboça uma possível explicação do motivo para saber e não contar. Trata-se de um desejo de não falar de coisas ruins, dolorosas.

Rodrigo - E me diz uma coisa. Tu acha que esse bloqueio assim, pra saber dessas histórias, é só teu, assim, de acreditar que isso foi real, se é tão horrível, ou tu acha que tem um bloqueio delas também pra contar?

Cleci - Olha, é aquela história, tu gosta de lembrar de coisa ruim? Rodrigo - Uh-hum.

Cleci - Pra que falar as coisas, sabe ${ }^{8}$

Também sua prima Terezinha Marques da Rocha atribui à dor latente nessas memórias uma explicação para a resistência, não de suas avós, mas de suas tias, para relatarem tais histórias. Não se trata de "lembrança boa" e, portanto, "não se faz questão de lembrar". 9 A complexa dinâmica da memória da escravidão foi sublinhada por Gilroy (2001, p. 413), que destacou a necessidade de se lidar com "o desejo de esquecer os terrores da escravidão e a impossibilidade simultânea de esquecer”. Ainda assim, o pouco que sabem é através das tias, e não da avó. Tais processos de silenciamento de aspectos proibidos, indizíveis ou vergonhosos da memória foram esmiuçados por Pollak (1989, p. 6-8), que argumentou que não se trata de esquecimento, mas de aspectos dificilmente verbalizáveis, quer pela intensa carga de sofrimento a eles vinculados, quer pela ausência de uma escuta, ou mesmo pela pretensão de poupar descendentes de crescerem com a lembrança daquelas feridas.

7 Entrevista com Arli Marques Correia e Maria Marques Correia Mendes, no dia 19 de novembro de 2010, no Caconde. Grifos meus.

8 Entrevista com Cleci Terra da Silva, no dia 21 de novembro de 2010, em Osório.

9 Entrevista com Terezinha Marques da Rocha, no dia 15 de outubro de 2010, em Osório. 
Percebe-se uma interrupção nos circuitos de memória do cativeiro na primeira geração nascida após o cativeiro, o que irá repercutir entre seus netos. A explicação encontrada por Terezinha e Cleci para o silêncio de suas avós e para a economia de palavras de suas tias, isto é, a dimensão dolorosa presente nas memórias do cativeiro, deveria se amplificar nos últimos anos do século XIX e nas décadas iniciais do século XX, quando o que estava em jogo era a afirmação de uma ideia de cidadania contrastiva ao cativeiro e às marcas por ele impostas aos sujeitos sociais em questão.

Mattos (1997, 1998, 2000, 2005a) assinala que vigorou, no século XIX, em momentos de igualdade formal, uma ética de silêncio quanto à cor e à experiência escrava pretérita. A abolição da distinção entre homens livres e escravos coroa o processo verificado pela autora ao longo do século XIX. Cria-se, assim, terreno fértil para o silenciamento de memórias do cativeiro, especialmente entre nascidos durante a vigência da Lei do Ventre-livre e nas primeiras décadas após o fim do cativeiro, já que queriam afirmar-se livres. Segundo Pollak (1989, p. 7), determinadas experiências podem ser dificilmente dizíveis quando contrapostas a uma narrativa socialmente hegemônica. No contexto da República Velha, de construção de uma ideia de cidadania contrastiva ao cativeiro, este não convinha ser lembrado.

Curiosamente, uma prima distante dos anteriormente citados, Maria Conceição Dias Nunes - sua bisavó, Tereza, era irmã de Felisberta, bisavó dos demais - da mesma faixa etária, conhece narrativas sobre o tempo da escravidão com um grau de precisão superior ao de suas primas. Sabe o nome da senhora que havia posto os escravos em liberdade e os trabalhos domésticos a que sua bisavó se dedicava. Porém, o grande diferencial é que Conceição conheceu e conviveu com a bisavó centenária, com quem aprendeu a fazer crochê e outras lides domésticas e que a acalmou quando, menina, temia que o tempo dos escravos voltasse. ${ }^{10}$ Mais do que se contrapor aos exemplos anteriores, este caso os confirma, já que as narrativas nas quais Conceição inspirou seu conhecimento sobre o passado dos escravos remetem à geração que penou no cativeiro, e não à geração de seu avô.

10 Entrevista com Maria Conceição Dias Nunes, no dia 17 de outubro de 2010, em Osório 


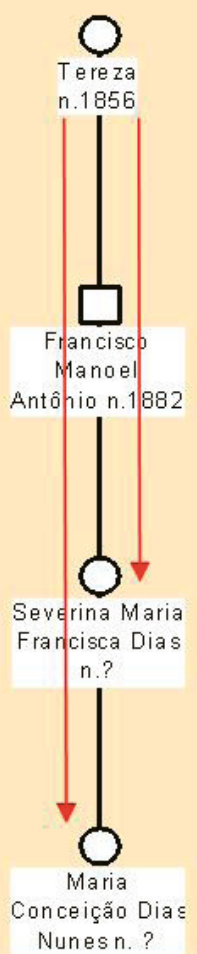

\section{Escravos}

Ventre-livre

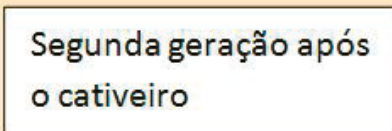

Terceira geração após o cativeiro

Organograma 3. Relatos a respeito da memória da escravidão na família de Maria Conceição Dias Nunes (Fonte: entrevistas com integrantes da família e registros paroquiais de batismo de Osório - Arquivo da Cúria Diocesana de Osório e Igreja de Jesus Cristo dos Santos dos Últimos Dias).

Um caso diferente, cujo organograma exponho a seguir, oferece uma exceção para o modelo aqui esboçado. Trata-se de Luís e Wilson Marques da Rosa, descendentes de Rosalina, irmã de Mercedes e cunhada de Clara. Segundo ambos os depoentes, sua avó lhes contava histórias antigas. Porém, no primeiro caso, indagado sobre os motivos que teriam levado sua avó a estabelecer-se em Osório, disse que devia ter a ver com os escravos, ${ }^{11}$ o que

11 Entrevista com Luís Marques da Rosa, no dia 23 de janeiro de 2009, na Prainha. Na ocasião da entrevista, Luís tinha 53 anos. 


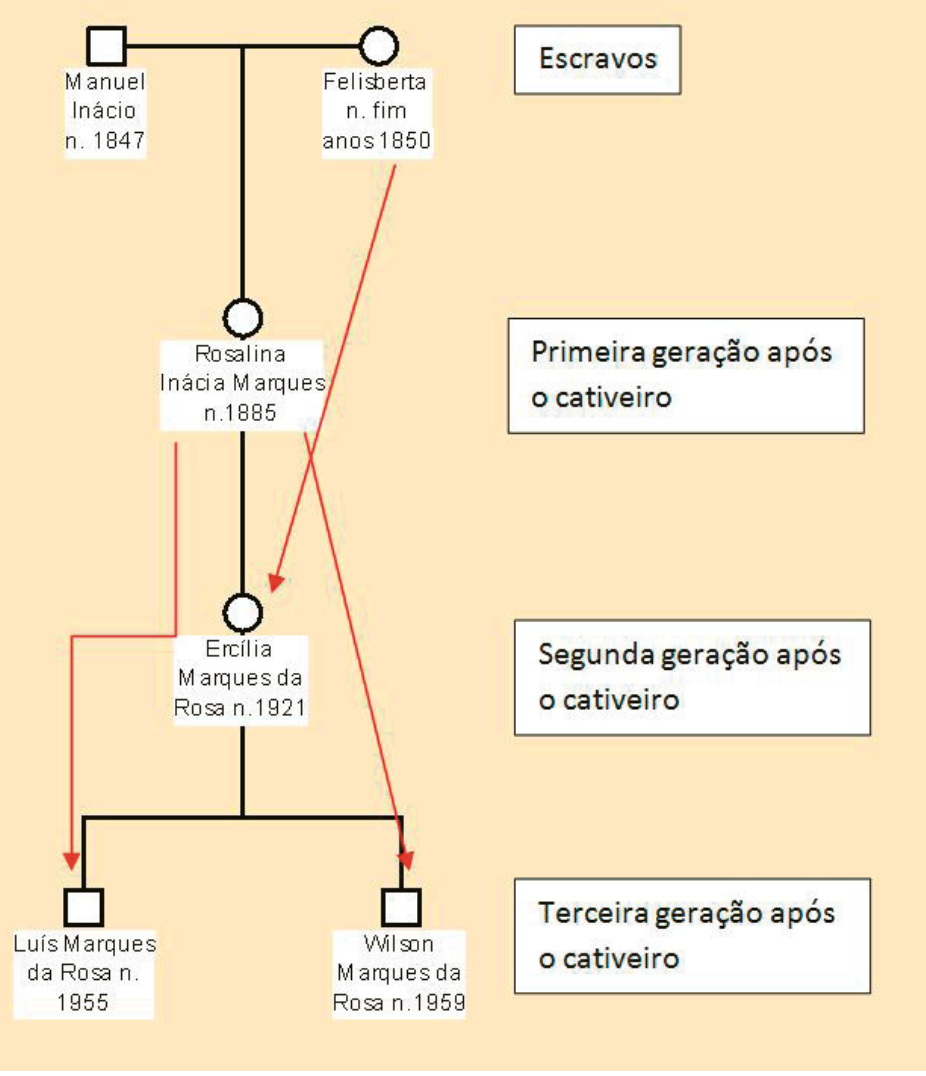

Organograma 4. Relatos a respeito da memória da escravidão na família de Ercília Marques da Rosa (Fonte: entrevistas com integrantes da família, registros paroquiais de batismo de Osório - Arquivo da Cúria Diocesana de Osório e Igreja de Jesus Cristo dos Santos dos Últimos Dias -, inventário de Manoel Inácio Osório Marques - Arquivo Público do Estado do Rio Grande do Sul - e Rosa, 1999).

indica um relato inexato, já que a migração se deu na primeira geração após o cativeiro. Ele afirma que ela lhe contava "histórias de quando era nova", porém ele não se lembrava dessas histórias, que até podem não dizer respeito ao cativeiro. Esta última resposta pode representar um esforço por parte de Luís para acelerar o processo de entrevista e se desvencilhar do pesquisador, na medida em que ele estava visivelmente apressado naquele momento. Por esta razão, ao representar graficamente esse circuito de memória, coloquei uma flecha "quebrada”, já que a recordação também o é. 
Contrastante é a narrativa de Wilson Marques da Rosa, que recorda de sua avó Rosalina narrando histórias do tempo da escravidão, tais como dos quilombos de Torres, Morro Alto e Palmares, da fuga de negros de um navio encalhado no Capão da Canoa, da resistência negra em uma revolução no Capão da Negrada. Ao contrário das avós de seus primos, Rosalina relatavalhe histórias a respeito da luta dos negros na região. Mas, principalmente, o mais importante era instar seu neto a empreender uma luta pela recuperação das terras doadas pela senhora Rosa Osório Marques.

Wilson - Me falava essa questão da terra, que era tudo nosso, que eles nunca tinham entregado, que de vez em quando tinham que fazer essa luta pra pedir devolução desse nosso território [...] Mas, assim, o que ela, o que ela batia mesmo era na questão da terra. Das fazendas que a Rosa deixou, a Rosa Osório Marques deixam pra ela, pra eles, né, e o... e o Estado não entrega, eles não entregam, eles tomaram tudo e não é só Morro Alto. Ela falava muito, dizia que eram três sesmarias e meia de campo que foi deixado pra eles, né, três sesmarias e meia de campo, cada sesmaria é 13.700 hectares, então, são $40 \ldots$ dá quase $40 \ldots 48.000$ hectares; então, pega Terra de Areia, pega Osório, pega Maquiné, pega Itati, é, pega São Francisco, Rolante, Riozinho, tá tudo dentro dessa área que foi deixada pela Rosa; e ela deixa duas fazendas: fazenda de Morro Alto, que era considerada a fazenda de Morro Alto, e a fazenda de Capivari do Sul. Por isso que ela batia... ela batia muito nisso, né? Que quando eu crescesse que tinha que fazer essa luta, que tinha que ir atrás desse território. E eu era... eu era. pra ela eu um... eu era rico, ela me chamava de bem criado, eu era um neto bem criado e os outros guris ela chamava de malcriado e brigava com a mãe, que eles não atendiam ela. Eu tirava a comadre, eu levava chá, ajudava ela a... a... a se virar na cama, né, que ela tinha muita ferida, ajudava a fazer os curativos... ${ }^{12}$

É necessário colocar a fala de Wilson em perspectiva quanto ao lugar de onde ele está falando. Ele é o presidente da Associação de Moradores de Morro Alto, que empreende a luta pela titulação das terras daquela comunidade, reconhecida como remanescente de quilombos. Assim sendo, é natural que enfatize a resistência negra na região, da qual o atual processo apresenta-se

12 Entrevista com Wilson Marques da Rosa, no dia 20 de janeiro de 2010, em Capão da Canoa. Wilson tinha 51 anos na ocasião da entrevista. 
como continuidade; e a luta pela terra, que aparece como uma designação de sua avó, à qual ele dedicava todo o carinho e atenção. Cria-se, para utilizar a expressão de Pollak (1989, p. 8) uma conjuntura favorável à emergência de uma memória coletiva marginalizada.

A luta política encontra fundamento ao redescobrir - e mesmo reviver e dar expressão jurídica a - uma perspectiva histórica a respeito dos quilombos, como bem assinala Chagas (2005, f. 103-111). Também a narrativa histórica assenta-se em uma demanda política corrente, em um verdadeiro "diálogo dos tempos" (Mattos, 2005b). ${ }^{13}$ Desse diálogo participaram também pesquisadores, instados a produzir relatórios técnicos a respeito de uma vivência comunitária demandados por esta luta política. Nunca é demais lembrar os ensinamentos dos primeiros Annales, segundo os quais os historiadores direcionam seu questionário a respeito do passado a partir de demandas que lhe são contemporâneas, e jamais de uma observação passiva (Bloch, 1992; Febvre, 1989).

O presidente da Associação de Moradores de Morro Alto relatou para a antropóloga Miriam Chagas narrativa muito similar àquela aqui apresentada, o que sugere o papel estrutural desse momento na gênese de sua busca por aquelas terras. "Eu enrolava os palheiros para ela; ${ }^{14}$ desde pequeno ela sempre me dizia para eu buscar essas terras, é uma busca de familia." (Chagas, 2005, f. 145, grifo da autora). A autora disserta a respeito do papel da caminhada para a descoberta de direitos (Chagas, 2005, f. 119-120). No caso em questão, porém, a procura, a busca tem um caráter familiar, e está inscrita em vínculos afetivos. Segundo a autora, "nessa dimensão, a procura do direito está envolta por este âmbito de busca de familia, como uma forma de dizer que estão dando continuidade, passando adiante, a noção de justiça legada de seus antepassados" (Chagas, 2005, f. 145, grifo da autora). Portanto, ao encabeçar a luta pelas terras de Morro Alto, Wilson concretiza um compromisso assumido.

Wilson constrói, em sua entrevista, uma narrativa biográfica na qual a luta pela terra aparece como destino manifesto e missão pessoal. A ele cabia empreendê-la, desde a determinação de sua avó para que o fizesse até as

13 Embora a autora utilize a expressão para aludir ao diálogo entre memórias referentes ao cativeiro e ao pós-Abolição, não considero descabido seu emprego no sentido aqui colocado, isto é, entre as demandas políticas do tempo presente e o "passado" recordado.

14 Seu irmão também recorda ter feito cigarros de palheiro para a avó, mas em seu relato não há menção de ela lhe indicar a luta pelas terras. Este aspecto está presente apenas na recordação de Wilson, que foi o único que assim o indica como um compromisso de vida. 
instruções para tal conferidas por Romildo Bolzan, político do Partido Democrático Trabalhista, ao qual sua família era muito ligada e com o qual Wilson foi trabalhar, em Porto Alegre, na Assembleia Legislativa do Estado do Rio Grande do Sul. ${ }^{15}$ A partida para a cidade e a inserção nos meios políticos urbanos oportunizaram o posterior engajamento na luta pelo reconhecimento de Morro Alto como remanescente de quilombos - e, conforme relata, foi apenas com este objetivo que aceitou trasladar-se da Prainha. ${ }^{16}$ Os fatos do passado são organizados na medida em que dão sentido à situação vivida no presente, naquilo que se designa de "ilusão biográfica" (Bourdieu, 1998). Trata-se de uma maneira de dar coerência simbólica e sentido ao vivido.

Hebe Mattos analisa a trajetória de uma liderança quilombola no estado do Rio de Janeiro, Antônio Nascimento Fernandes - Toninho - também percebendo a saída da comunidade como missão para a melhoria de suas condições de vida, através do compromisso assumido com os avós. Acredito que as conclusões da autora possam ser extensivas à história narrada por Wilson, cuja trajetória guarda tantas semelhanças com a de Toninho:

Ao unir passado, presente e futuro, numa fala feita de improviso (ele não trouxe quaisquer anotações), a conferência [a entrevista] de Toninho [de Wilson] surpreende pela coerência e estruturação, a revelar alguém com reflexões prévias sobre si próprio e suas relações com a história do grupo. Confere, assim, ao conjunto dos moradores da fazenda, uma identidade, uma determinada personalidade coletiva atualizada, construída nas relações de parentesco, na prática do jongo [do maçambique] e na luta conjunta pela posse da terra do novo quilombo - e não mais apenas na memória do cativeiro dos seus antepassados na Fazenda São José [do Morro Alto] (Mattos, 2005a, p. 293. Os trechos entre colchetes são adequações de minha autoria).

Embora Wilson e seus primos contrastem no sentido de o primeiro sentir-se apto a relatar memórias do cativeiro e os demais não, existem semelhanças geracionais. As memórias acionadas por ele referem-se à resistência negra na região e ao direito pela terra representado pela doação mas, como os demais, ele encontra dificuldades para situar com exatidão as relações de parentesco entre seus ancestrais. Ao contrário da geração anterior, ele não

15 Entrevista com Wilson Marques da Rosa, no dia 20 de janeiro de 2010, em Capão da Canoa.

16 A Prainha é a localidade de origem da família de Wilson, nas circunvizinhanças de Morro Alto, um pouco ao norte, entre o Morro Maquiné e a Lagoa dos Quadros. 
possui uma memória genealógica aguçada, o que, talvez, não seja o fundamental para ele. No já discutido episódio em que ele cuidava da avó, que o encarregou de lutar pelas terras de Morro Alto, na entrevista feita comigo, ele afirmou tratar-se de Rosalina e, para Chagas, disse que era a bisavó Felisberta, com a qual, até onde eu saiba, ele não chegou a conviver. No entanto, configura-se, mais do que uma imprecisão propriamente dita, uma memória genealógica difusa e uma percepção da história que confere maior importância à delegação de uma luta do que propriamente ao personagem da história familiar que o teria feito.

Ao longo da entrevista com ele realizada, em mais de um momento foi interrompido por sua esposa, a historiadora Marilda Aparecida Souza da Rosa, que o corrigiu ou complementou dados dos quais não se recordava. Marilda realizou minucioso trabalho de história oral com sua sogra, a falecida Ercília Marques da Rosa, e tinha uma noção mais microscópica dos fatos familiares, enquanto a recordação de Wilson era mais macroscópica e referente à história negra na região.

\section{O tipo dos escravos}

Venho afirmando que as narrativas sobre o cativeiro de avós escravos encontraram repercussão entre seus netos, hoje octogenários, por sua inserção no mercado de trabalho, ainda sem acesso a direitos trabalhistas. Muito embora as primeiras leis trabalhistas remetam à década de 1930, tudo indica que haja uma lenta difusão para áreas mais interiorizadas do país, como é o caso do município de Osório: os entrevistados, ao menos, não os acessaram de imediato. Mesmo ao se dirigirem para o meio urbano, na década de 1940, as narradoras lembram dos direitos trabalhistas como algo a que tiveram acesso bastante tempo após o processo migratório. A historiografia mais contemporânea tem criticado a ideia de que os direitos trabalhistas e o impacto do governo varguista foram inócuos no meio rural (Dezemone, 2004, 2009; Ribeiro, 2009). Tais autores destacaram que, por diversos meios, trabalhadores rurais procuraram a justiça referenciados em parâmetros jurídicos do direito trabalhista, dirigiram cartas a Vargas apresentando suas reivindicações e vivenciaram, nessa ocasião, uma decadência do poder dos grandes fazendeiros. Deve-se considerar, ainda assim, que seu impacto fora de áreas urbanas, se significativo, foi indireto e informal. 
Curiosamente, dona Aurora credita a Getúlio Vargas, de forma integral, a responsabilidade por leis trabalhistas a que teve acesso apenas anos depois de trabalhar no meio urbano. Dito em outros termos, os muitos anos de governo Vargas, em que existia carteira de trabalho e a ela não teve direito, restam esquecidos. O período anterior à obtenção do documento não é lembrado como governo varguista. $\mathrm{O}$ momento em que dona Aurora obteve sua carteira é identificado como aquele em que o governante o concedeu. $\mathrm{O}$ mais importante na organização desse processo em sua memória é a associação da figura de Getúlio Vargas como instituinte da passagem de um momento de não direito a outro de possibilidade de usufruir das leis trabalhistas. Tal ocasião é representada a partir da imagem mítica de Getúlio concedendo liberdade e direitos a escravos que viviam em sua fazenda.

Aurora - Ele tinha uma fazenda que era só escravo.

Rodrigo - Ele tinha?

Aurora - Uhum. O Getúlio.

Rodrigo - Que que aconteceu com esses escravos do Getúlio?

Aurora - Ah, ele libertou, ele ajudava, ele fazia tudo que era bom. Eva - Eu acho que sim. ${ }^{17}$

Dona Aurora e dona Eva sabem muito bem que o regime escravista se extinguiu em 1888, e certamente esses "escravos" de Getúlio eram trabalhadores sem acesso a direitos sociais, como de resto os demais - brancos ou negros - de seu período. Trata-se de uma comparação para dar conta da situação daqueles que trabalharam tipo dos escravos. Dona Aurora interpreta os atos da Princesa Isabel e de Getúlio Vargas como dois momentos distintos de um mesmo processo de emancipação. A libertação dos escravos pela princesa teria sido um ato de inspiração divina, uma graça, enquanto a ação de Getúlio, algo pertencente à esfera e à caridade humanas; a primeira teria deixado os escravos "por conta deles", enquanto a segunda, instituiu-os como indivíduos verdadeiramente livres por serem portadores de direitos. ${ }^{18}$

Se a escravidão é tida como tempo, por excelência, de ausência de direitos (Barcellos et al., 2004, p. 259-379; Chagas, 2005, f. 171-180), os governos

17 Entrevista com dona Aurora Inácia Marques da Silva e Eva Inácia Marques, no dia 9 de janeiro de 2010, em Osório.

18 Entrevista com dona Aurora Inácia Marques da Silva, no dia 13 de março de 2010, em Osório. 
trabalhistas, mais do que a princesa Isabel, são concebidos como os extintores do regime escravista (Dezemone, 2004, f. 125-135; Gomes; Mattos, [s.d.]; Mattos, 2005a, p. 54-55). Mais do que isso, Aurora percebe a si mesma como alguém que, por não ter usufruído da carteira de trabalho e por não ter tido horas de descanso e regulamentação da jornada de trabalho, se não foi escrava, trabalhou tipo dos escravos, traçando um paralelo entre o regime laboral vivido por seus avós e por ela mesma.

Aurora - Os direitos, assinar carteira, a... respeitar as horas de serviço, então mudou. Porque é que, quando eu comecei a trabalhar, que eu tinha 14 anos, não tinha domingo, não tinha dia santo, não tinha feriado, não tinha nada.

Rodrigo - Não tinha nada.

Aurora - Não tinha nada. Era... Era tipo dos escravos.

Rodrigo - Era tipo dos escravos?

Aurora - [enfática] Era o tipo dos escravos. Eu trabalhei no tipo, ainda, ainda peguei um pedaço no tipo dos escravos. ${ }^{19}$

Ora, tendo vivido condições de trabalho consideradas similares às do cativeiro, as memórias "transmitidas" por seus avós encontravam um terreno fértil para serem reinterpretadas, rememoradas e reproduzidas - e mais: chave explicativa para a própria situação por ela vivida. É algo muito distinto da geração de seus sobrinhos, que passaram a participar do mercado de trabalho após os direitos trabalhistas estarem consolidados (inclusive fora do meio urbano - Arli goza de aposentadoria rural), para os quais as narrativas sobre o passado escravo, se estão sempre presentes e configuram uma identidade que não se esquece, restam, todavia, alheias às suas próprias experiências de trabalho, ao contrário de seus pais.

\section{Conclusão}

Se há "transmissão" da memória, é necessário que existam também condições adequadas de locução por parte do polo "transmitente", e de assimilação, reinterpretação, rememoração e reprodução por parte do polo

19 Entrevista com dona Aurora Inácia Marques da Silva, no dia 13 de março de 2010, em Osório. 
“receptor". Infelizmente, os dados de que disponho não permitem uma avaliação mais precisa a respeito dos motivos para a locução sobre tais memórias por parte da geração de escravos. Uma coisa é certa: Merêncio e Felisberta contaram para seus netos narrativas sobre o cativeiro tanto quanto Mercedes e Clara não o fizeram. Afinal, Eva, Aurora e Diva lembram do que "seus avós lhes contavam". Resta responder a uma questão da qual não consegui dar conta neste trabalho. Se, nos anos iniciais do século XX, como já foi dito, estava em jogo a afirmação de uma cidadania contrastiva com a lembrança da experiência escrava e a identificação com ela, por qual razão esses dois ex-cativos julgaram importante manter essas vivências presentes entre seus netos? Dito em outros termos, por que o "silenciamento" a respeito das memórias do cativeiro parece ter atingido filhos de escravos muito mais do que eles mesmos?

Há que se considerar que tanto Merêncio quanto Felisberta eram legatários do testamento dirigido pela senhora escravista Rosa Osório Marques para seus cativos e descendentes. Talvez tenha havido uma positivação da experiência cativa através do testamento. Ser descendente de escravos representava um legado de sofrimentos e de recordações ruins, mas também uma expectativa de direitos. Não é pouco significativo que, quando perguntei quem eram os antigos escravos do Morro Alto, os entrevistados só souberam falar de famílias aparentadas aos arrolados em tal testamento.

Talvez a aposta na obtenção dos terrenos não fosse tão relevante para a geração posterior. Manoel Inácio Filho, filho de Felisberta e marido de Clara, e Mercedes, nora de Merêncio, pertenciam a famílias que, bem ou mal, lograram estabelecer-se como camponeses independentes no Espraiado e no Faxinal do Morro Alto. É possível que a "geração de camponeses" se sentisse menos seduzida pela possibilidade de uma herança em terras da longínqua senhora de seus pais, se sentisse contente com as terras ocupadas e se aferrasse à construção de uma cidadania sem enfatizar os vínculos com o cativeiro. Na geração seguinte, porém, de Eva, Aurora e Diva, os conflitos fundiários na região do Morro Alto exacerbaram-se e o testamento de Rosa Marques foi uma importante peça em batalhas simbólicas e judiciais (Barcellos et al., 2004; Chagas, 2005).

Se as condições de trabalho vividas na juventude conferem à segunda e à terceira gerações nascidas após o cativeiro interesses diferenciados pelas histórias que seus avós - mais ou menos predispostos a contar - relembravam a respeito do cativeiro, a atual conjuntura, de luta fundiária e de emergência de etnicidade, traz um interesse renovado pela história regional e familiar. Certamente isto está por trás das falas do presidente da Associação de Moradores 
de Morro Alto, que se mostra tão interessado e bem informado acerca do passado da região. No entanto, como visto, não se trata da mesma memória da geração anterior, visto que menos minuciosa genealogicamente.

Isto leva, também, a uma reflexão a respeito do processo de pesquisa, já que o investigador involuntariamente se converte em partícipe e mediador de um diálogo intergeracional. Portelli (2010, p. 20) ressaltou que o pesquisador, por meio de sua presença, perguntas e reações, desencadeia processos de memória. No caso por mim analisado, minha presença implicou momentos de socialização intergeracional de relatos sobre o passado escravista.

Já relatei a ocasião em que, diante do não saber dos filhos (real ou pressuposto), dona Eva demonstrou o seu saber, compartilhando não apenas com o pesquisador, mas também com seus rebentos, seus conhecimentos a respeito do que se estava demandando, isto é, o passado familiar. Poderia lembrar ainda das entrevistas realizadas para a elaboração do laudo de reconhecimento de Morro Alto como remanescente de quilombos com a falecida dona Ercília, às quais seu filho Wilson assistiu e das quais participou, ${ }^{20}$ ou da ocasião em que exibi, para dona Aurora, um DVD em que gravei uma entrevista com ela registrada em meio audiovisual, e que foi assistida também por sua sobrinha Terezinha, atenta, interessada e jocosa. Aquilo que é uma descoberta para o investigador, também o é para a nova geração, e esse processo é fomentado pelo processo de pesquisa.

\section{Referências}

BARCELLOS, D. M. et al. Comunidade negra de Morro Alto: historicidade, identidade e direitos constitucionais. Porto Alegre: Editora da UFRGS, 2004.

BLOCH, M. Introducción a la historia. 17. ed. México: Fondo de Cultura Económica, 1992.

BOURDIEU, P. A ilusão biográfica. In: AMADO, J.; FERREIRA, M. de M. (Org.). Usos e abusos da história oral. 2. ed. Rio de Janeiro: Fundação Getúlio Vargas, 1998. p. 183-191.

CATROGA, F. Memória, história e historiografia. Coimbra: Quarteto Editora, 2001.

CERTEAU, M. de. A invenção do cotidiano. 9. ed. Petrópolis: Vozes, 1994.

20 Não está descartada a possibilidade de que parte das memórias que Wilson atribui à sua avó tenha sido obtida através do convívio com sua mãe, nesse processo de compartilhamento de memórias a partir da pesquisa de Morro Alto. 
CHAGAS, M. de F. Reconhecimento de direitos face aos (des)dobramentos da História: um estudo antropológico sobre territórios de quilombos. Tese (Doutorado em Antropologia)Universidade Federal do Rio Grande do Sul, Porto Alegre, 2005.

CHARTIER, R. Escribir las prácticas: discurso, práctica, representación. Valencia: Fundación Cañada Blanch, 1998.

DEZEMONE, M. Memória camponesa: identidades e conflitos em terras de café (18881987). Fazenda Santo Inácio, Trajano de Moraes - RJ. Dissertação (Mestrado em História Social)-Universidade Federal Fluminense, Niterói, 2004.

. A era Vargas e o mundo rural brasileiro: memória, direitos e cultura política camponesa. In: MOTTA, M.; ZARTH, P. Formas de resistência camponesa: visibilidade e diversidade de conflitos ao longo da história: vol. 2. São Paulo: Editora da Unesp; Brasília: Ministério do Desenvolvimento Agrário, NEAD, 2009. p. 73-98.

FEBVRE, L. Combates pela história. 3. ed. Lisboa: Presença, 1989.

GILROY, P. O Atlântico negro. São Paulo: Ed. 34; Rio de Janeiro: Universidade Candido Mendes, Centro de Estudos Afro-Asiáticos, 2001.

GOMES, A. de C.; MATTOS, H. M. Sobre apropriaçôes e circularidades: memória do cativeiro e política cultural na Era Vargas. [s.d.]. Disponível em: <http://www.historia.uff. br/culturaspoliticas/files/hebe3.pdf >. Acesso em: 19 fev. 2010.

JANOTTI, M. de L. M.; ROSA, Z. de P. Transmissão da memória sobre a escravidão. História, São Paulo, n. 14, p. 111-123, 1995.

MATTOS, H. M. Laços de família e direitos no final da escravidão. In: ALENCASTRO, L. F. de (Org.). História da vida privada no Brasil 2: Império: a corte e a modernidade nacional. Coleção dirigida por Fernando Novais. São Paulo: Companhia das Letras, 1997.

. Das cores do silêncio: significados da liberdade no Sudeste escravista. Brasil, século XIX. 2. ed. Rio de Janeiro: Nova Fronteira, 1998.

. Escravidão e cidadania no Brasil monárquico. Rio de Janeiro: Jorge Zahar, 2000.

. Novos quilombos: re-significações da memória do cativeiro entre descendentes da última geração de escravos. In: MATTOS, H. M.; RIOS, A. Memórias do cativeiro: família, trabalho e cidadania no pós-Abolição. Rio de Janeiro: Civilização Brasileira, 2005a. p. 257-301.

. Memórias do cativeiro: narrativa e identidade negra no antigo Sudeste cafeeiro. In: MATTOS, H. M.; RIOS, A. Memórias do cativeiro: família, trabalho e cidadania no pósAbolição. Rio de Janeiro: Civilização Brasileira, 2005b. p. 35-135. 
POLLAK, M. Memória, esquecimento, silêncio. Estudos Históricos, Rio de Janeiro, v. 2, n. 3, p. 3-15, 1989.

PORTELLI, A. Tentando aprender um pouquinho: algumas reflexões sobre a ética na História Oral. Projeto História, São Paulo, n. 15, p. 13-49, abr. 1997.

. Ensaios de história oral. São Paulo: Letra e Voz, 2010.

RAPHAËL, F. Le travail de la mémoire et les limites de l'histoire orale. Annales: Économies Societés Civilisations. Paris, n. 35, v. 1, p. 127-144, janv./févr. 1980.

RIBEIRO, V.V. Cartas ao presidente Vargas: outra forma de luta pela terra. In: MOTTA, M.; ZARTH, P. Formas de resistência camponesa: visibilidade e diversidade de conflitos ao longo da história: vol. 2. São Paulo: Editora da Unesp; Brasília: Ministério do Desenvolvimento Agrário, NEAD, 2009. p. 53-72.

Resumo: Discuto, neste artigo, circuitos da memória sobre a escravidão entre descendentes de cativos do litoral norte do Rio Grande do Sul, analisando como tais memórias foram "transmitidas" entre gerações. Entende-se aqui a "transmissão" da memória não como processo passivo, mas como mecanismo de apropriação, interpretação e reprodução das histórias narradas pelos avós conforme circunstâncias contemporâneas, principalmente uma inserção no mercado de trabalho à margem da legislação trabalhista, considerada similar às situações de cativeiro relatadas pelos avós. Verificou-se, ainda, o privilégio do circuito avô-neto, e não paifilho, na "transmissão" da memória da escravidão e também um silenciamento a respeito de tais narrativas por parte da primeira geração nascida após o cativeiro.

Palavras-chave: memória, escravidão, leis trabalhistas.

"My grandpa told me": dynamics of circulation of the slavery memory among descendants of slaves. Osório, $20^{\text {th }}$ century

\begin{abstract}
I discuss, in this article, slavery memory circuits among slaves descendants at the northern littoral of Rio Grande do Sul. I analyse how those memories were "transmited" between generations. We understand, here, that the "transmission" of memory wasn't a passive process. It was a mechanism of appropriation, interpretation and reproduction of the stories related by their grandfathers and grandmothers according to contemporaneous circumstances. Among those circumstances, there was a insertion in the labor market outside the labor laws. This insertion was considered similar to the situations of slavery related by their grandfathers. There was, also, a privilege of the circuit grandfather-grandson, and not father-son, in the "transmission" of slavery memory, as well a silence about those narratives by the first generation born after slavery.
\end{abstract}

Keywords: memory, slavery, labor laws.

Recebido em 05/06/2011

Aprovado em 10/08/2011 